\title{
USE OF LEGAL RESERVE AREAS AS GEOCHEMICAL BACKGROUND IN HYDROSEDIMENTOLOGY STUDIES $^{(1)}$
}

\author{
Carlos Roberto Juchen ${ }^{(2)}$, Márcio Antônio Vilas Boas ${ }^{(3)}$, Cristiano Poleto ${ }^{(4)}$ \& Maurício \\ Macedo $^{(5)}$
}

\begin{abstract}
SUMMARY
In hydrosedimentology studies the determination of the trace element concentrations at the study site is imperative, since this background can be used to assess the enrichment of sediments with these elements. This enrichment can be the result of the natural process of geological formation or of anthropogenic activities. In the latter case, guidelines are used to indicate the concentrations at which trace elements cause ecotoxicity effects on the environment. Thus, this study used legal reserve areas in the municipality of Toledo, PR, where natural forests are maintained, with no or minimal human interference to establish background levels. The results of atomic emission spectrometry with inductively coupled argon plasma showed that the legal reserves have lower levels of trace elements than other theoretical references, but equivalent concentrations to the safety levels recommended by international guidelines. It was concluded that determining values is fundamental to recommend this background as scientific database for research in the area of hydrosedimentology of this site and also as a way of environmental management of the watershed of this municipality.
\end{abstract}

Index terms: natural heavy metal levels, conservation areas, environmental quality.

(1) Part of the first author's Doctoral Thesis. Received for publication on September 4, 2013 and approved on July $25,2014$.

(2) Professor, Universidade Tecnológica Federal do Paraná - UTFPR, Campus Toledo. Rua Cristo Rei, 19, Vila Becker. CEP 85902490 Toledo (PR), Brasil. E-mail: crjuchen@utfpr.edu.br

(3) Professor, Universidade Estadual do Oeste do Paraná - UNIOESTE. Rua Universitária, 2069, Jardim Universitário. CEP 85819-110 Cascavel (PR), Brazil. E-mail: marcio.vilasboas@unioeste.br

(4) Professor, UTFPR, Campus Toledo. E-mail: poleto@utfpr.edu.br

(5) Technical director and researcher at ALLABOR - Laboratórios de Alimentos. Av. Parigot de Souza, 190, Jardim Porto Alegre. CEP 85906-070 Toledo (PR), Brazil. E-mail: mauricio.macedo@allabor.com.br 


\title{
RESUMO: UTILIZAÇÃODE ÁREAS DE RESERVA LEGAL COMOBACKGROUND GEOQUÍMICO EMESTUDOS HIDROSSEDIMENTOLÓGICOS
}

\begin{abstract}
Em estudos de hidrossedimentologia é imprescindivel que se tenha o levantamento dos teores de elementos-traço do local de pesquisa, uma vez que esse background pode ser utilizado para interpretações do enriquecimento desses elementos no local da pesquisa. Esse enriquecimento pode estar relacionado ao processo natural de sua formação geológica ou às ações antropogênicas, sendo nesse último caso utilizado os guidelines, que apresentam as concentrações em que os elementos-traço causam efeitos de ecotoxicidade no ambiente. Assim, este estudo utilizou áreas com florestas naturais denominadas de reserva legal para formação do background do municipio de Toledo, PR, as quais asseguram condições de nenhuma ou mínima interferência antrópica. Os resultados da espectrometria de emissão atômica com plasma de argônio acoplado indutivamente demonstraram que as reservas legais possuem teores de elementos-traço inferiores aos demais referenciais teóricos pesquisados, porém em concentrações equivalentes aos níveis de segurança dos recomendados pelos guidelines internacionais consultados. Concluiu-se que os valores determinados são fundamentais para recomendar esse background como base de dados científicos para pesquisas da área de hidrossedimentologia desse local e também como forma de gerenciamento ambiental da bacia hidrográfica desse município.
\end{abstract}

Termos de indexação: teores naturais de metal pesado, áreas de preservação, qualidade ambiental.

\section{INTRODUCTION}

Human activities may directly and significantly contribute to environmental contamination by trace elements (TEs), whereas high concentrations in the soil may interfere with the environment, changing the productivity, biodiversity and sustainability of ecosystems as well as posing risks to humans and animals (Kede et al., 2008). The potential damage by these elements is aggravated when absorbed by plants and when exceeding the maximum retention capacity of the soil, becoming easily leachable, resulting in groundwater discharge (Pandolfo et al., 2008).

In Brazil, a set of guiding values for environmental soil quality is defined by Resolution $\mathrm{N}^{\circ} 420 / 2009$ of the National Environmental Council (Conama) and by a Normative Rule $\mathrm{N}^{\circ} 195 / 2005$ - $\mathrm{E}$ of the Environmental Protection Agency in São Paulo (Cetesb), establishing Reference Quality Values (RQV), Prevention Values (PV) and Investigation Values (IV). Thus, the RQV for each of the TEs is based on the analysis of soil under natural conditions (without or with minimal human interference), while PV and IV are determined by assessing and analyzing the environmental risk (Conama, 2009).

According to Galuszka (2007), one of the most important issues in recent environmental studies concerns the establishment of geochemical background values for organic elements and compounds in biotic and abiotic systems. According to the author, the relationship between natural changes and those caused by anthropogenic action on chemical species is an issue with important implications in the fields of geology, biology and toxicology and other fields of knowledge. This is particularly important when a geochemical analysis of toxic element concentrations is required.
Thus, background is defined as a theoretically natural concentration of a substance or element in a sample, considering the temporal and spatial variables in the area under investigation (Galuszka, 2006). Also, the International Organization for Standardization (ISO, 2005) recommends that the environmental background of a substance or metal in the soil be defined as a frequency distribution parameter of commonly found levels, i.e., the natural contents of these elements in the soil (Zhao et al., 2007).

Given the lack of specific regional backgrounds that can support studies on hydrosedimentology, this paper establishes a background for eutroferric Red Latosol with the use of soil samples with preserved/ undisturbed characteristics of the geological formation, and, consequently, unaltered levels of trace elements, for being located in legal reserves of rural properties in Toledo, PR.

\section{MATERIAL AND METHODS}

Figure 1a,b shows Toledo in western Paraná, and the five legal reserves in the surroundings of the municipality (Table 1).

The soil is classified as eutroferric Red Latosol with a low silt/clay ratio and the absolute or virtual absence of easily weatherable primary minerals (Embrapa, 2013). In each of the five legal reserves, soil samples were randomly extracted with a stainless steel shovel from a depth of $0-20 \mathrm{~cm}$. One of the three samplings was carried out in the rainy season to eliminate any hydrodynamic influence on TE concentrations.

In the laboratory, samples were dried in an air circulation oven at $45^{\circ} \mathrm{C}$ and after cooling, ground in 

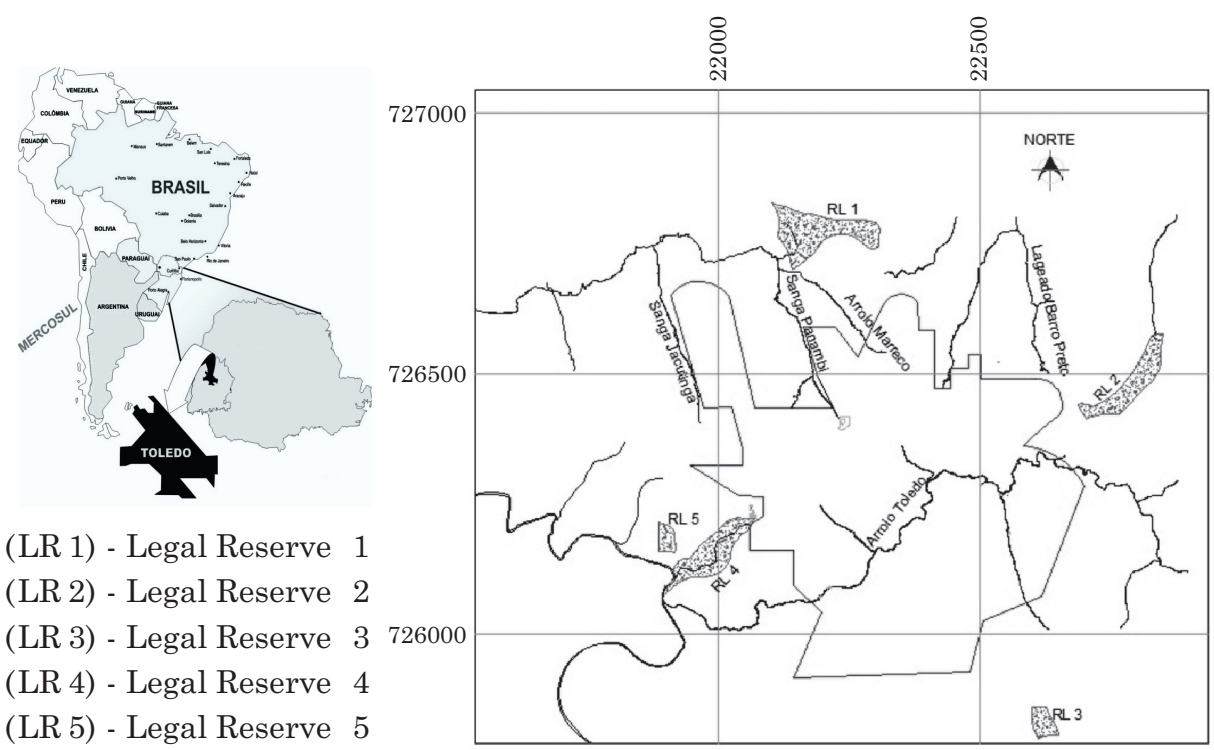

(LR 1) - Legal Reserve 1

(LR 2) - Legal Reserve 2

(LR 3) - Legal Reserve 3726000

(LR 4) - Legal Reserve 4

(LR 5) - Legal Reserve 5

Figure 1. Geographical location of the study area (a) South America, Brazil, Paraná, Toledo; and (b) urban perimeter and location of legal reserves.

Table 1. Sampling description (geochemical background) in study areas

\begin{tabular}{|c|c|c|c|c|}
\hline Point & Geographic coordinate & Location & Legal reserve characteristic & Altitude \\
\hline LR1 & $\mathrm{S} 24^{\circ} 40^{\prime} 48^{\prime \prime}-\mathrm{W} 53^{\circ} 45^{\prime} 21^{\prime \prime}$ & Northern region & $\begin{array}{l}\text { Vegetation of subtropical broadleaf forest, } \\
\text { with predominant species of peroba tree }\end{array}$ & $\begin{array}{c}\mathrm{m} \\
585 \\
578\end{array}$ \\
\hline LR2 & $\mathrm{S} 24^{\circ} 42^{\prime} 35^{\prime \prime}-\mathrm{W} 53^{\circ} 41^{\prime} 23^{\prime \prime}$ & Northeast region & (Anpidosperma polyneuron), cedar & 580 \\
\hline LR3 & $\mathrm{S} 24^{\circ} 46^{\prime} 10^{\prime \prime}-\mathrm{W} 53^{\circ} 42^{\prime} 16^{\prime \prime}$ & Southern region & (Cedrela odorata), cabreúva (Myroxylon & 492 \\
\hline $\mathrm{LR} 4$ & $\mathrm{~S} 24^{\circ} 44^{\prime} 49^{\prime \prime}-\mathrm{W} 53^{\circ} 45^{\prime} 59^{\prime \prime}$ & Southwest region & perniferun), bay laurel (Laurus & \\
\hline LR5 & S $24^{\circ} 43^{\prime} 59^{\prime \prime}-\mathrm{W} 53^{\circ} 46^{\prime} 10^{\prime \prime}$ & East region & $\begin{array}{l}\text { nobilis), pau-d'alho (Gallesia integrifolia), } \\
\text { ipê (Tabebuia spp.), pau marfim } \\
\text { (Balfourodendron riedelianum) and others }\end{array}$ & 571 \\
\hline
\end{tabular}

an agate mortar and sieved $(<2 \mathrm{~mm})$ through Teflon mesh to recover approximately $10 \mathrm{~g}$ of the soil fraction (Conama, 2009). To digest the samples, the updated USEPA 3051 method was used (microwave) of the American Public Health Association (APHA, 1998), as recommended by Conama $n^{0} 420 / 2009$. The analytical practice of the Standard Methods $\left(22^{\text {nd }}\right.$ 2011) method by inductively coupled plasma-atomic emission spectroscopy (ICP-OES), model Optima 8000 ICP - Perkin Elmer.

The data were transformed by the logarithm function: $\log (\mathrm{x}+1)$, as the results had a large variation in dimensional values resulting in a positive asymmetrical distribution. To determine the background, the descriptive and multivariate statistical analysis was chosen, and in the latter case, data were reoriented by Principal Component Analysis (PCA), in which the axes were selected based on the "Broken Stick" (Jackson, 1993) randomization model.

\section{RESULTS AND DISCUSSION}

Table 2 shows efficiency parameters of the applied analytical methods, by comparison of the concentrations of the species of interest with the standard reference material Green River Shale, SGR-1b from USGS (United States Geological Survey).

The mean results and their relative deviations (extraction efficiency) from the reference standard were obtained in aqueous matrices with minimum limits of quantification. The chemical analysis included concentration ranges significantly close to those expected. The accuracy calculated by the relative standard deviations (RSD) varied from 3.66 to $9.63 \%$ for $\mathrm{Cu}$ and $\mathrm{Pb}$, respectively; and, therefore, less than $10 \%$ for all elements analyzed. According to Milagres et al. (2007), for accurate and reproducible results, the coefficient of variation (CV) in a series of determinations (precision) can vary up to $10 \%$, while the CV between different series (reproducibility) 
should be less than $20 \%$. Considering that the $3051 \mathrm{~A}$ method using concentrated nitric acid is a method of incomplete sample decomposition, the recovery rates in this study were very significant for all elements analyzed compared with other studies with much more energetic digestions, as used by Vieira et al. (2005).

\section{Regional reference values (RRV)}

Table 3 shows the results of a descriptive statistical analysis to determine the local background levels referred to in this study as the regional reference values (RRV).

As reported by Ker (1997), the eutroferric Red Latosols collected in legal reserves are clayey or very clayey, a texture condition given by the low quartz concentration in the source material. The same author stated that the mineralogy of this type of Latosol typically has a coarse fraction of magnetite $(\mathrm{FeO}$, $\mathrm{Fe}_{2} \mathrm{O}_{3}$ ) with predominance of magnetite intergrown with ilmenite $\left(\mathrm{FeTiO}_{2}\right)$, resulting in the high $\mathrm{Fe}$ concentrations $\left(105,956 \mathrm{mg} \mathrm{kg}^{-1}\right)$ observed in this study. The significant concentrations of other TEs also indicate the potential fertility of this soil due to the presence of total $\mathrm{P}$ and some trace elements, such as $\mathrm{Mn}, \mathrm{Ni}, \mathrm{Cu}, \mathrm{Zn}$, and Co (Ker, 1997).

The results in table 3 show concentrations below 0.005 (As and Se), 0.01 (U) and 0.1 (B) in $\mathrm{mg} \mathrm{kg}^{-1}$, indicating little potential for dispersion of these elements in this watershed. It was expected that the $\mathrm{B}$ contained in the soil organic fraction of these legal reserve would range from 0.1 to $0.6 \mathrm{mg} \mathrm{kg}^{-1}$, but according to Rosolem \& Bíscaro (2007), this element can be largely reduced by leaching losses.

Table 2. Values obtained from the Green River Shale reference sample (SGR-1b) of USGS

\begin{tabular}{|c|c|c|c|c|c|}
\hline \multirow{2}{*}{ Element } & \multirow{2}{*}{ Blank } & \multicolumn{2}{|c|}{ Standard } & \multicolumn{2}{|c|}{ Determined by ICP - OES } \\
\hline & & Mean \pm SD & RSD & Mean \pm SD & RSD \\
\hline As & $<0.005$ & $67 \pm 5$ & 7.46 & $34.52 \pm 2.87$ & 8.32 \\
\hline $\mathrm{Ba}$ & 0.003 & $290 \pm 40$ & 13.79 & $221.22 \pm 15.66$ & 7.08 \\
\hline $\mathrm{Cu}$ & 0.013 & $66 \pm 9$ & 13.63 & $64.15 \pm 2.34$ & 3.66 \\
\hline $\mathrm{Cd}$ & 0.008 & 0.9 & - & $0.79 \pm 0.07$ & 8.86 \\
\hline $\mathrm{Cr}$ & 0.016 & $30 \pm 3$ & 10.00 & $26.26 \pm 1.01$ & 3.85 \\
\hline $\mathrm{Mn}$ & 0.003 & $267 \pm 34$ & 12.73 & $209.88 \pm 9.53$ & 4.54 \\
\hline $\mathrm{Ni}$ & 0.005 & 29 & - & $21.63 \pm 1.38$ & 6.74 \\
\hline $\mathrm{Pb}$ & 0.017 & $38 \pm 4$ & 10.52 & $33.72 \pm 3.25$ & 9.63 \\
\hline $\mathrm{Zn}$ & 0.048 & $74 \pm 9$ & 12.16 & $61.75 \pm 5.27$ & 8.54 \\
\hline
\end{tabular}

SD: standard deviation; RSD: relative standard deviations.

Table 3. Mean regional reference values (RRV) obtained from the five legal reserves

\begin{tabular}{|c|c|c|c|c|c|}
\hline Metal & $\mathbf{n}^{(1)}$ & $\bar{x}(R R V)^{(2)}$ & $\sigma^{(3)}$ & $\mathrm{CV}^{(4)}$ & $C I^{(5)}(\alpha=95 \%)$ \\
\hline & & & & $\%$ & \\
\hline $\mathrm{Al}$ & 15 & 102,372 & 551 & 0.54 & $101,828-103,599$ \\
\hline As & 10 & $<0.005$ & - & - & - \\
\hline $\mathrm{B}$ & 10 & $<0.1$ & - & - & - \\
\hline $\mathrm{Ba}$ & 15 & 62.51 & 28.56 & 45.69 & $32.86-128.89$ \\
\hline $\mathrm{Cu}$ & 15 & 212.3 & 57.20 & 26.95 & $114.40-322.60$ \\
\hline $\mathrm{Cd}$ & 10 & 0.69 & 0.10 & 13.83 & $0.55-0.90$ \\
\hline $\mathrm{Cr}$ & 15 & 54.2 & 19.63 & 36.22 & $16.02-92.78$ \\
\hline $\mathrm{Fe}$ & 15 & 105,956 & 666 & 0.63 & $104,699-107,141$ \\
\hline $\mathrm{Mn}$ & 15 & 916.4 & 342.1 & 37.33 & $537.7-1,707.7$ \\
\hline $\mathrm{Mg}$ & 15 & $2,303.2$ & 136.1 & 5.91 & $2,036.2-2,440.3$ \\
\hline $\mathrm{Na}$ & 15 & 1493.1 & 346.2 & 23.19 & $1,009.1-2,367.9$ \\
\hline $\mathrm{Ni}$ & 15 & 30.26 & 9.55 & 31.56 & $8.62-43.94$ \\
\hline $\mathrm{Pb}$ & 15 & 17.46 & 2.39 & 13.68 & $12.57-20.69$ \\
\hline $\mathrm{Sb}$ & 15 & 4.58 & 0.69 & 15.10 & $3-5.87$ \\
\hline $\mathrm{Se}$ & 10 & $<0.005$ & - & - & - \\
\hline $\mathrm{U}$ & 10 & $<0.01$ & - & - & - \\
\hline $\mathrm{Zn}$ & 15 & 82.14 & 13.79 & 16.79 & $57.91-114.97$ \\
\hline
\end{tabular}

${ }^{(1)} \mathrm{n}$ : number of repetitions; ${ }^{(2)} \overline{\mathrm{x}}$ : mean (RRV: Regional Reference Values); ${ }^{(3)} \sigma$ : standard deviation; ${ }^{(4)}$ CV: coefficient of variation;

(5) CI: confidence interval. 
The analysis of the coefficients of variation may indicated great variability in the concentrations of RRV, although the concentrations were, on average, higher than the quality reference values proposed for metals in soils of São Paulo by Casarini (2000) for the elements: $\mathrm{Cd}(0.5), \mathrm{Cu}$ (35.1), $\mathrm{Cr}$ (40.2), $\mathrm{Ni}$ (13.2), $\mathrm{Pb}$ (17), and $\mathrm{Zn}$ (59.9) in $\mathrm{mg} \mathrm{kg}^{-1}$ and were also higher than those proposed by Campos et al. (2003) for 19 Brazilian Latosols, using the same method (USEPA 3051A) for the elements: Cd (0.66 \pm $0.19), \mathrm{Cu}(65 \pm 7.4), \mathrm{Ni}(18 \pm 12)$, and $\mathrm{Zn}(39 \pm 24)$ in $\mathrm{mg} \mathrm{kg}{ }^{-1}$. Thus, different land uses could explain the lower values obtained in this study and, on the other hand, demonstrate that legal reserves maintain higher levels of these elements for preserving their original characteristics of their formation.

The current understanding of the soil quality concept is based on the balance between geological, hydrological, chemical, physical, and biological soil conditions (Sposito \& Zabel, 2003), but metals such as $\mathrm{Al}, \mathrm{Fe}$ and $\mathrm{Mn}$, presenting RRV in high average concentrations of 102,372, 105,956 and $916.4 \mathrm{mg} \mathrm{kg}^{-1}$, respectively, may interfere with the concentration of other metals, since their oxides and hydroxides are minerals that occur in discrete phases or in combination with other minerals in the form of coatings, aside from having a high specific surface, micropores and different adsorption sites, which gives them a significant action in mobility, distribution and attenuation of trace metals (Axe \& Trivedi, 2002). Also, the metals $\mathrm{Pb}, \mathrm{Cu}, \mathrm{Zn}$ and $\mathrm{Ni}$, despite not changing their oxidation state, may be indirectly affected by changes in the soil redox potential for their strong association with $\mathrm{Fe}$ and Mn oxides, which are susceptible to changes in the oxidation state (Axe \& Trivedi, 2002). In expansive clay minerals and the oxides and hydroxides of $\mathrm{Fe}, \mathrm{Al}$ and $\mathrm{Mn}$, metals can also be trapped in negative sites present in the crystal structures (octahedral spaces), forming inner sphere complexes (Sposito, 2008).

Table 4 shows the Pearson correlation analysis $(p<0.05)$, eigenvalues, percentage of explanation and the "Broken-Stick" value. Problems occurred in the digestion of the samples and the variables with zero values were presented together with indices 1 or 2 , for the lowest and highest number of repetitions, respectively.

This correlation table was organized in decreasing order, with the largest negative or positive factorial loads indicating extreme TE concentrations in this mineralogical matrix, since correlations can identify and quantify variations in soil associated with pedogenic processes (Carvalho Junior et al., 2008). High positive correlations (>0.8) mainly for $\mathrm{Mn}_{2}$ and $\mathrm{Fe}_{2}$; and negative correlations $(<-0.8)$ for the elements $\mathrm{Ni}_{2}, \mathrm{Cr}_{2}, \mathrm{Sb}_{2}$ and $\mathrm{Pb}_{2}$ are not always of environmental interest. For example, Mn oxides can be bound to essential TEs for plants $(\mathrm{Co}, \mathrm{Cu}, \mathrm{Zn}$, or $\mathrm{Mo}$ ) and also strongly adsorb polluting elements such as $\mathrm{Pb}$ and $\mathrm{Cd}$, which, at higher concentrations, had toxic effects on eutroferric Red Latosols in the region of Missões, Rio Grande do Sul (Meurer, 2006).

Through eigenvalues greater than expected at random, the principal component analysis (PCA) summarized the three main components according to the Broken-Stick criteria. Thus, figure 2 shows the graphs of the first three principal components (PC), to observe the behavior of variables included in each of these components as well as the variable behavior in the legal reserves (LR).

The first component (PC1), with an eigenvalue of $\lambda=9.91$ (Table 4 ), accounted for $52 \%$ of the variability and was influenced by most metals, more positively by $\mathrm{Mn}, \mathrm{Fe}, \mathrm{Ba}$, and $\mathrm{Al}$ and negatively by $\mathrm{Na}, \mathrm{Zn}, \mathrm{Ni}$, $\mathrm{Mg}, \mathrm{Cr}, \mathrm{Sb}$, and $\mathrm{Pb}$, with high bivariate correlations $(r>0.60)$. This component segregated LR5 (Figure 2) from the others by presenting, together, the highest concentrations of metals with positive association and the lowest concentrations of metals with negative association.

The second component (PC2), with an eigenvalue of $\lambda=5.58$, accounted for $29 \%$ of the variability and was influenced by only five metals - positively by Ba, $\mathrm{Mn}, \mathrm{Cu}, \mathrm{Cr}$, and $\mathrm{Ni}$ and with high bivariate correlations $(r>0.6)$; and negatively by none of the metals. This component segregated LR4 from the others by the concentration of metals with positive association for this set of elements (Figure 2). Finally, the third component (CP3) showed an eigenvalue of $\lambda=2.84$ and accounted for only $15 \%$ of the variability, and was negatively influenced by the metals $\mathrm{Zn} 1$, Cd1 and Na2 with high bivariate correlations; this component segregated LR1 (Figure 2) from the others by concentrations of other metals with negative association for this set of elements.

The results show that the most complete analysis $(n=15)$ defines the ordering of the variables with indices 2 in CP1, and thus explain most of the information in the original data set which makes the visualization more direct and, therefore, the subsequent analyses more practical (Lattin et al., 2011). Figure 2 shows that CP1 is highely similar to LR2 and LR5, which are located on opposite sides of the municipality. The LR4 is located near LR5 and is ordered in different components and LR1 kept its ordination in both projections and is located north of the city. Thus, these results and observations show that the legal reserves are apparently homogeneous due to their formation and preservation characteristics, but this homogeneity cannot be applied to TEs, due to the geochemical differentiation of the earth's crust, which affects the differential distribution of TEs within the same geological formation (Mello \& Abrahão, 2013).

The three components explained $96 \%$ of the variability and no source of geogenic or anthropogenic 
Table 4. Values of correlation, eigenvalues, percentage of explanation and "Broken Stick" retention coefficient for variables of legal reserves

\begin{tabular}{|c|c|c|c|c|c|c|c|c|c|c|c|c|c|c|c|c|c|c|c|c|c|c|}
\hline & CP1 & CP2 & CP3 & Mn2 & $\mathrm{Fe} 2$ & $\mathrm{Al} 2$ & $\mathrm{Ba} 2$ & Ba1 & Mn1 & Cr1 & Cu1 & Ni1 & $\mathrm{Zn1}$ & Cd1 & $\mathrm{Na} 2$ & $\mathrm{Cu} 2$ & $\mathrm{Zn} 2$ & $\mathrm{Ni} 2$ & Mg2 & Cr2 & $\mathrm{Sb2}$ & $\mathrm{Pb} 2$ \\
\hline $\mathrm{Mn} 2$ & 0.9 & 0.0 & -0.3 & 1.0 & & & & & & & & & & & & & & & & & & \\
\hline $\mathrm{Fe} 2$ & 0.9 & 0.3 & -0.4 & 0.8 & 1.0 & & & & & & & & & & & & & & & & & \\
\hline $\mathrm{Al} 2$ & 0.7 & 0.6 & -0.1 & 0.5 & 0.9 & 1.0 & & & & & & & & & & & & & & & & \\
\hline $\mathrm{Ba} 2$ & 0.7 & 0.6 & -0.3 & 0.8 & 0.8 & 0.7 & 1.0 & & & & & & & & & & & & & & & \\
\hline Ba1 & -0.1 & 1.0 & -0.2 & 0.0 & 0.2 & 0.5 & 0.5 & 1.0 & & & & & & & & & & & & & & \\
\hline Mn1 & -0.2 & 0.9 & -0.4 & -0.1 & 0.3 & 0.5 & 0.4 & 0.9 & 1.0 & & & & & & & & & & & & & \\
\hline Cr1 & 0.4 & 0.9 & 0.3 & 0.3 & 0.4 & 0.7 & 0.7 & 0.7 & 0.5 & 1.0 & & & & & & & & & & & & \\
\hline $\mathrm{Cu} 1$ & 0.6 & 0.8 & 0.3 & 0.4 & 0.6 & 0.8 & 0.7 & 0.6 & 0.5 & 1,0 & 1.0 & & & & & & & & & & & \\
\hline Ni1 & 0.6 & 0.7 & 0.2 & 0.4 & 0.7 & 0.9 & 0.7 & 0.6 & 0.5 & 0.9 & 1.0 & 1.0 & & & & & & & & & & \\
\hline $\mathrm{Zn} 1$ & 0.3 & 0.1 & -1.0 & 0.6 & 0.6 & 0.3 & 0.6 & 0.3 & 0.4 & -0.1 & 0.0 & 0.0 & 1.0 & & & & & & & & & \\
\hline $\mathrm{Cd} 1$ & -0.6 & 0.0 & -0.8 & -0.3 & -0.2 & -0.3 & -0.2 & 0.3 & 0.4 & -0.5 & -0.6 & -0.6 & 0.6 & 1.0 & & & & & & & & \\
\hline $\mathrm{Na} 2$ & -0.6 & -0.5 & -0.6 & -0.4 & -0.4 & -0.6 & -0.5 & -0.2 & 0.0 & -0.8 & -0.9 & -0.9 & 0.4 & 0.9 & 1.0 & & & & & & & \\
\hline $\mathrm{Cu} 2$ & -0.8 & 0.6 & 0.2 & -0.8 & -0.6 & -0.3 & -0.3 & 0.6 & 0.5 & 0.2 & 0.0 & 0.0 & -0.3 & 0.4 & 0.1 & 1.0 & & & & & & \\
\hline $\mathrm{Zn} 2$ & -0.8 & 0.5 & -0.2 & -0.6 & -0.5 & -0.3 & -0.2 & 0.6 & 0.6 & 0.1 & -0.1 & -0.2 & 0.1 & 0.7 & 0.4 & 0.9 & 1.0 & & & & & \\
\hline $\mathrm{Ni} 2$ & -0.9 & 0.4 & 0.2 & -0.9 & -0.7 & -0.3 & -0.5 & 0.5 & 0.5 & 0.1 & -0.1 & -0.2 & -0.3 & 0.4 & 0.3 & 1.0 & 0.9 & 1.0 & & & & \\
\hline Mg2 & -0.9 & 0.5 & 0.0 & -0.8 & -0.6 & -0.3 & -0.3 & 0.6 & 0.6 & 0.1 & -0.1 & -0.2 & -0.1 & 0.6 & 0.3 & 1.0 & 1.0 & 1.0 & 1.0 & & & \\
\hline $\mathrm{Cr} 2$ & -1.0 & 0.3 & 0.0 & -0.9 & -0.8 & -0.5 & -0.5 & 0.4 & 0.4 & -0.1 & -0.3 & -0.4 & -0.2 & 0.6 & 0.4 & 0.9 & 0.9 & 1.0 & 1.0 & 1.0 & & \\
\hline $\mathrm{Sb} 2$ & -1.0 & 0.2 & 0.0 & -0.8 & -0.8 & -0.6 & -0.5 & 0.4 & 0.3 & -0.1 & -0.4 & -0.4 & -0.2 & 0.6 & 0.5 & 0.9 & 0.9 & 0.9 & 1.0 & 1.0 & 1.0 & \\
\hline $\mathrm{Pb} 2$ & -1.0 & 0.1 & 0.0 & -0.8 & -0.8 & -0.7 & -0.6 & 0.3 & 0.2 & -0.2 & -0.5 & -0.5 & -0.3 & 0.6 & 0.5 & 0.9 & 0.9 & 0.9 & 0.9 & 1.0 & 1.0 & 1.0 \\
\hline & 9.91 & 5.58 & 2.84 & \multicolumn{3}{|c|}{ Eigenvalues } & & & & & & & & & & & & & & & & \\
\hline & 52.16 & 29.39 & 14.92 & \multicolumn{3}{|c|}{$\%$ of explanation } & & & & & & & & & & & & & & & & \\
\hline & 52.16 & 81.54 & 96.46 & \multicolumn{3}{|c|}{$\%$ total } & & & & & & & & & & & & & & & & \\
\hline & 3.55 & 2.55 & 2.05 & \multicolumn{4}{|c|}{ Broken-Stick eigenvalues } & & & & & & & & & & & & & & & \\
\hline
\end{tabular}
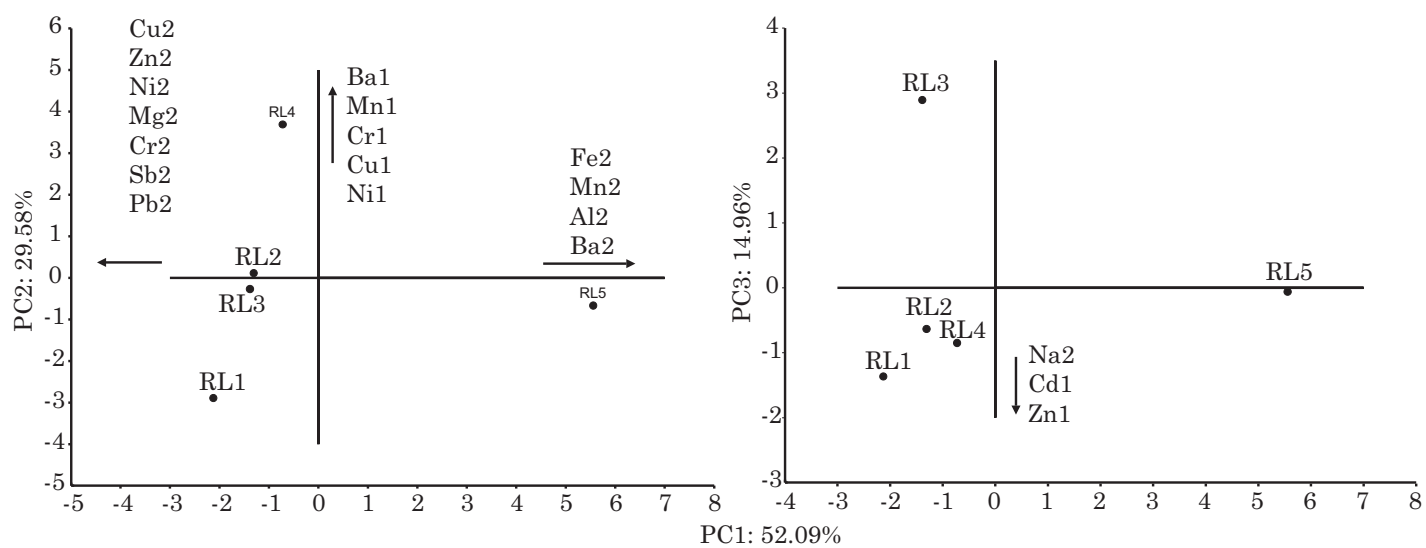

Figure 2. Scores of legal reserves obtained on major components and system variables (arrows) applied to the Pearson correlation matrix between metals of the soil samples [concentration transformed into log $(x+1)$ to approximate normality conditions].

contamination could be identified by these components. Thus, it can be concluded that the natural TE concentration in this soil is greatly influenced by the source material and by the result of the combined action of geomorphological/climate processes or conditions, which make the TE levels found in this study specific. This fact confirms studies with materials of distinct origin and soil classes, in which variability of heavy metal levels was observed resulting from the pedogenic processes affecting these source materials (Vázquez \& Anta, 2009).

\section{RRV and Brazilian backgrounds}

The background values and tolerance limits established for the elements $\mathrm{Cd}, \mathrm{Co}, \mathrm{Cr}, \mathrm{Cu}, \mathrm{Ni}, \mathrm{Pb}$, and $\mathrm{Zn}$, were determined predominantly in samples of distroferric Red Latosol, distroferric Red Nitosol, Brown Latosol and eutroferric Red Argisol (Table 5), herein denominated group G1 (Fadigas et al., 2006). These studies demonstrated that the main physical, chemical and mineralogical characteristics of soils can influence the background values, including clay, Mn, $\mathrm{Fe}$ contents and cation exchange capacity (CEC). 
Also, table 5 shows the results of backgrounds established in the State of Rio Grande do Sul with some TE levels determined in soil samples or sediments from preserved natural areas, the arithmetic mean TE values in 43 soil samples from Paraná determined by the geological service of Paraná - Mineropar (2005) and the values established by Resolution $\mathrm{N}^{\circ} 420$ of Conama (2009) in which the soil quality is characterized by the PV and IV.

The backgrounds in this table were used for studies in analyses of anthropogenic enrichment of river and urban sediments (Poleto \& Merten, 2008a,b; Poleto et al. 2009; Poleto \& Cardoso, 2012), and the values differ substantially from the determined RRV. Thus, it is always essential to establish the background in order to draw conclusions in environmental contamination studies, since the specific properties of the pedogenetic formation or environmental factors can substantially affect the mobility and availability of TEs.

The RRV were close to the background presented by Fadigas et al. (2006). Also, the Latosol samples were undisturbed or nearly undisturbed by human activity. Only $\mathrm{Cu}$ reached levels close to the threshold established by these authors, but above the IV for agricultural soil indicated by Conama (2009), which can be justified by the fact that Toledo, PR, is located in the central portion of the third plateau of Paraná, with an area with peculiar anomalous $\mathrm{Cu}$ values (318.8 $\mathrm{mg} \mathrm{kg}^{-1}$ ) related to basic igneous rocks of the Serra Geral formation (Mineropar, 2005).

It was also observed that the RRV levels of the TEs Ba, Cr, Se, and U were lower than those cited by Mineropar (2005) and PV established by Resolution $\mathrm{N}^{\circ} 420$ of Conama (2009). However, the other metals had similar or higher levels, since the geochemical survey was conducted with soil samples from unpreserved sites, unlike the legal reserves in this study.

\section{RRV and guidelines}

In this study, one of the concerns was the occurrence of enrichment of some TEs in the legal reserves, by the natural geological formation or through human actions. Therefore, the determined RRV (Table 6) were compared to the limit and intervention concentrations of the Dutch guideline, adopted by European countries in numerous pollution studies as a means of assessing contamination levels (Macklin et al., 2003; Lee et al., 2005) and also compared to the maximum allowable TE concentrations in sediments established by Conama (2004) for material disposal.

These data show a significant extrapolation for $\mathrm{Cu}$, with levels requiring intervention, thus emphasizing the need for surveying the local background to be used in any study on TEs and the appropriate contamination levels in this environment. In this sense, Poleto \& Gonçalves (2006) report that the specificity of each reference value is also clear when comparing the thresholds established by the Dutch with the Canadian guideline. The values found for studies in the Netherlands are very high when compared to the ones used in Canada, mainly due to mineralogical differences of each country, showing how extremely risky it is to take the studies produced in other regions or countries as a background of data for metals.

In this table, the RRV for $\mathrm{Cr}$ is on the probability threshold of causing adverse effects on freshwater biota

Table 5. Elements-trace concentration recommended by Conama, Paraná average values, G1 and their thresholds, background and RRV

\begin{tabular}{|c|c|c|c|c|c|c|c|c|c|c|}
\hline \multirow{3}{*}{ Metal } & \multicolumn{4}{|c|}{ Conama } & \multirow{3}{*}{ Parana } & \multirow{3}{*}{ G1 group } & \multirow{3}{*}{ Threshold } & \multirow{2}{*}{\multicolumn{2}{|c|}{ Background }} & \multirow{3}{*}{$R R V^{(3)}$} \\
\hline & \multirow{2}{*}{$\mathrm{PV}^{(1)}$} & \multicolumn{3}{|c|}{$I V^{(2)}$} & & & & & & \\
\hline & & Agricultural & Residen & ndustrial & & & & 2008 & 2012 & \\
\hline & & & & & $\mathrm{mg} \mathrm{kg}^{-1}$ & & & & & \\
\hline $\mathrm{Ba}$ & 150 & 300 & 500 & 750 & 170,84 & n.a. & - & & & 62,51 \\
\hline $\mathrm{Cu}$ & 60 & 200 & 400 & 600 & 141,72 & 119 & 283 & & & 212,3 \\
\hline $\mathrm{Cd}$ & 1,3 & 3 & 8 & 20 & 0,18 & 1 & 2 & 0,07 & 0,07 & 0,69 \\
\hline Co & 25 & 35 & 65 & 90 & 23,84 & 29 & 44 & 19,00 & & n.a. \\
\hline $\mathrm{Cr}$ & 75 & 150 & 300 & 400 & 105,42 & 55 & 114 & & & 52,4 \\
\hline Mn & & & & & 736,84 & n.a. & - & & & 916,4 \\
\hline $\mathrm{Ni}$ & 30 & 70 & 100 & 130 & 34,16 & 35 & 92 & & 4,89 & 30,26 \\
\hline $\mathrm{Pb}$ & 72 & 180 & 300 & 900 & 23,21 & 19 & 35 & & 31,30 & 17,46 \\
\hline $\mathrm{Sb}$ & & & & & 0,74 & n.a. & - & & & 4,58 \\
\hline $\mathrm{Se}$ & 5 & & & & 0,53 & n.a. & - & & & $<0,005$ \\
\hline $\mathrm{U}$ & & & & & 3,02 & n.a. & - & & & $<0,01$ \\
\hline $\mathrm{Zn}$ & 300 & 450 & 1000 & 2000 & 75,26 & 79 & 149 & & 47,45 & 82,14 \\
\hline
\end{tabular}


Table 6. Comparison of RRV to the maximum allowable trace element concentrations for disposal of dredged material established by Conama 344/2004 and limits and intervention concentration of the Dutch guideline

\begin{tabular}{|c|c|c|c|c|c|c|c|}
\hline \multirow{3}{*}{ Trace elemeny } & \multirow{3}{*}{$\operatorname{RRV}^{(1)}$} & \multicolumn{4}{|c|}{ Conama 344/2004 } & & \\
\hline & & \multicolumn{2}{|c|}{ Freshwater } & \multicolumn{2}{|c|}{ Brackish saline water } & \multicolumn{2}{|c|}{ Dutch Guideline $^{(5)}$} \\
\hline & & Level 1 & Level 2 & Level $1^{(3)}$ & Level $2^{(3)}$ & Limit & Intervention \\
\hline & & & 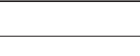 & $-\mathrm{mg} \mathrm{kg}^{-1}$ & & & \\
\hline As & $<0.005$ & $5.90^{(2)}$ & $17^{(2)}$ & 8.2 & 70 & 294 & 554 \\
\hline $\mathrm{Ba}$ & 62.51 & n.s. & n.s. & n.s. & n.s. & 1,604 & 6,254 \\
\hline $\mathrm{Cd}$ & 0.69 & $0.60^{(2)}$ & $3.5^{(2)}$ & 1.2 & 9.6 & 0.84 & 124 \\
\hline $\mathrm{Cr}$ & 54.20 & $37.30^{(2)}$ & $90^{(2)}$ & 81.0 & 370 & 1,004 & 3,804 \\
\hline $\mathrm{Cu}$ & 212.30 & $35.70^{(2)}$ & $197^{(2)}$ & 34.0 & 270 & 364 & 1,904 \\
\hline $\mathrm{Hg}$ & n.a. & $0.17^{(2)}$ & $0.486^{(2)}$ & 0.15 & 0.71 & 0.34 & 104 \\
\hline $\mathrm{Ni}$ & 30.26 & $18.00^{(4)}$ & $5.9^{(4)}$ & 20.9 & 51.6 & 354 & 2,104 \\
\hline $\mathrm{Pb}$ & 17.46 & $35.00^{(2)}$ & $91.3^{(2)}$ & 46.7 & 218 & 854 & 5,304 \\
\hline $\mathrm{Zn}$ & 82.14 & $123.00^{(2)}$ & $315^{(.2)}$ & 150.0 & 410 & 1,404 & 7,204 \\
\hline
\end{tabular}

${ }^{(1)}$ RRV: regional reference values (Toledo, PR). ${ }^{(2)}$ Environmental Canada (2002). ${ }^{(3)}$ Long et al. (1995). ${ }^{(4)}$ FDEP (1994). ${ }^{(5)}$ Netherlands Government (2000). n.a.: not analyzed; n.s.: not specified.

(level I) and the Ni is on the probability threshold of causing adverse effects on both freshwater and saltwater biota (level I). The $\mathrm{Cu}$ concentration has harmful effects on freshwater (level I and II) or saltwater (level I). However, these effects are not considered threatening by Conama when considering the possibility that these soils will be deposited in riverbeds of this watershed in the form of sediments and may result from a dredging process.

It is noteworthy that the concentrations of the TEs $\mathrm{As}, \mathrm{Pb}$ and $\mathrm{Zn}$ are presented in lower RRV than those of the aforementioned guideline (Table 6), thus, using only this guideline would allow TEs in higher concentrations than the levels naturally supported by this ecosystem. Thus, it is recommended that studies on environmental contamination be interpreted by criteria of the local geochemical survey (background), especially in view of the fact that natural sources of TEs may be considered harmful contaminants.

\section{CONCLUSIONS}

1. Recovery rates determined by the method of incomplete sample decomposition resulted in make the results more accurate and reproducible.

2 . The coefficients of variation of RRV exceeded $10 \%$ for most trace elements analyzed, resulting from the pedogenetic processes influencing the same source material.

3. The TE levels determined as RRV are, on average, higher than the reference values of quality for metals in soils of the State of São Paulo and also exceed the reference values proposed for 19 other Brazilian Latosols.

4. The correlation coefficients indicated the TEs with extreme values in the mineral matrix.

5. The PCA was ordered into three components that explained $96 \%$ of the variability of the results and showed that there was no geogenic or anthropogenic source of contamination in the legal reserves.

6 . The TE concentrations of the background of the eutroferric Red Latosols are below the guideline values, therefore these thresholds are permissible beyond the real tolerance level of the local ecosystem.

7. The background established in this study is indicated for TE monitoring in the watershed of Toledo PR or regions with similar characteristics.

\section{ACKNOWLEDGEMENTS}

The authors wish to thank the ALLABOR Food Laboratories, Toledo, PR, and the Brazilian Council for Scientific and Technological Development (CNPq), for funding this project.

\section{LITERATURE CITED}

AMERICAN PUBLIC HEALTH ASSOCIATION - APHA. Standard methods for the examination of water and wastewater. 20.ed. Washington, 1998. 1193p. 
AXE, L. \& TRIVEDI, P. Intraparticle surface diffusion of metal contaminants and their attenuation in microporous $\mathrm{Al}$, Fe, and Mn oxides. J. Coll. Interf. Sci., 247:259-265, 2002.

CAMPOS, M.L.; PIERANGELI, M.A.P.; GUILHERME, L.R.G. \& CURI, N. Baseline concentration of heavy metals in Brazilian Latosols. Commun. Soil Sci. Plant Anal, 34:547557, 2003.

CARVALHO JUNIOR, W.C.; SCHAEFER, C.E.G.R., CHAGAS, C.S. \& FERNANDES FILHO, E.I. Análise multivariada de Argissolos da faixa Atlântica Brasileira. R. Bras. Ci. Solo, 32:2081-2090, 2008.

CASARINI, D.C.P. Proposta de valores de referência de qualidade e intervenção para solos e águas subterrâneas no estado de São Paulo. In: SEMINÁRIO INTERNACIONAL SOBRE QUALIDADE DE SOLOS E ÁGUAS SUBTERRÂNEAS, 2., São Paulo, 2000. Anais... São Paulo, CETESB, 2000. p.165.

CONSELHO NACIONAL DO MEIO AMBIENTE - CONAMA. Resolução n ${ }^{\circ} 344$, de 25 de março de 2004. Disponível em: $<$ http://www.mma.gov.br/port/conama>. Acesso em 6 abr. 2013.

CONSELHO NACIONAL DO MEIO AMBIENTE - CONAMA. Resolução. $\mathrm{n}^{\circ}$ 420, de 28 de dez. de 2009 Disponível em $<\mathrm{http}$ ://www.m ma.gov.br/port/conama/ legiabre.cfm?codlegi=620>. Acesso em 11 jun. 2013.

EMPRESA BRASILEIRA DE PESQUISA AGROPECUÁRIA EMBRAPA. Sistema brasileiro de classificação de solos. Brasília, Embrapa Solos, 2013. 353p.

ENVIRONMENTAL CANADA. Canadian sediment quality guidelines for the protection of aquatic life. Canadian Environmental Quality Guidelines - Summary Tables. 2002. Available at: <http://www.ec.gc.ca>.

FADIGAS, F.S.; AMARAL SOBRINHO, N.M.B.; MAZUR, N.; ANJOS, L.H.C. \& FREIXO, A.A. Proposição de valores de referência para a concentração natural de metais pesados em solos brasileiros. R. Bras. Eng. Agríc. Amb., 10:699-705, 2006.

FLORIDA DEPARTMENT OF ENVIRONMENTAL PROTECTION - FDEP. Approach to the assessment of sediment quality in Florida Coastal waters. Vol. I. Development and evaluation of sediment quality assessment guidelines. Office of Water Policy, Tallahasee, FL, MacDonald Environmental Sciences Ltd., Ladysmith, British Columbia, 1994.

GALUSZKA, A. Methods of determining geochemical background in environmental studies. Problems of landscape ecology. Polish Assoc. Landscape Ecol., 16:507519, 2006.

GALUSZKA, A. A review of geochemical background concepts and an example using data from Poland. Environ. Geol., 52:861-870, 2007.

INTERNATIONAL ORGANIZATION FOR STANDARDIZATION - ISO. Soil quality: Guidance on the determination of background values. ISO 19258: 2005.

JACKSON, D.A. Stopping rules in principal components analysis: A comparison of heuristical and statistical approaches. Ecology, 74:2204-2214, 1993.
KEDE, M.L.F.M.; MOREIRA, J.C.; MAVROPOULOS, E.; ROSSI, A.M.; BERTOLINO, L.C.; PEREZ, D.V. \& ROCHA, N.C.C. Estudo do comportamento do chumbo em Latossolos brasileiros tratados com fosfatos: contribuições para a remediação de sítios contaminados. Quim. Nova, 31:579-584, 2008.

KER, J. Latossolos do Brasil: Uma revisão. Geonomos, 5:1740, 1997.

LATTIN, J.M.; CARROLL, J.D. \& GREEN, P.E. Análise de dados multivariados. São Paulo, Cengage Learning, 2011. 455p.

LEE, P.K.; YU, Y.H.; YUN, S.T. \& MAYER, B. Metal contamination and solid phase partitioning of metals in urban roadside sediments. Chemosphere, 60:672-689, 2005.

LONG, E.R.; MACDONALD, D.D.; SMITH, S.L. \& CALDER F.D. Incidence of adverse biological effects within ranges of chemical concentrations in marine and estuarine sediments. Environ. Manage., 19: 81-97, 1995.

MACKLIN, M.G.; BREWER, P.A.; BALTEANU, D.; COULTHARD, T.J.; DRIGA, B.; HOWARD, A.J. \& ZAHARIA, S. The long term fate and environmental significance of contaminant metals released by the January and March 200 mining tailings dam failures in Maramures country, upper Tisa Basin, Romania. Appl. Geochem., 18:241-257, 2003.

MELLO, J.W.V. \& ABRAHÃO, W.A.P. Valores de referência de qualidade para elementos-traço nos solos de Minas Gerais e Espírito Santo: os bastidores de uma experiência. B. Inf. SBCS, 38:14-17, 2013.

MEURER, E.J. Fundamentos de química do solo. Porto Alegre, Evangraf, 2006. 285p.

MILAGRES, J.J.M.; ALVAREZ V., V.H.; CANTARUTTI, R.B. \& NEVES, J.C.L. Determinação de Fe, Zn, Cu e Mn extraídos do solo por diferentes extratores e dosados por espectrofotometria de emissão ótica em plasma induzido e espectrofotometria de absorção atômica. R. Bras. Ci. Solo, 31:237-245, 2007.

MINERAIS DO PARANÁ S.A. - MINEROPAR. Levantamento geoquímico multielementar do Estado do Paraná. Geoquímica de solo - Horizonte B. Relatório final de projeto. Curitiba, 2005. v.1. 85p.

NETHERLANDS GOVERNMENT. Circular on target values and intervention values for soil remediation: $\mathrm{DBO} /$ 1999226863. Netherlands Gov. Gazet., 39:1-11, 2000.

PANDOLFO, C.M.; CERETTA, C.A.; MASSIGNAM, A.M.; VEIGA, M. \& MOREIRA, I.C.L. Análise ambiental do uso de fontes de nutrientes associados a sistemas de manejo do solo. R. Bras. Eng. Agríc. Amb., 12:512-519, 2008.

POLETO, C. \& CARDOSO, A.R. Concentrações de Zn e Ni em sedimentos urbanos de 30 municípios do Rio Grande do Sul: Riscos aos recursos hídricos estaduais. R. Bras. Rec. Hídric., 14:1-12, 2012.

POLETO, C.; BORTOLUZZI, E.C.; CHARLESWORTH, S. \& MERTEN, G.H. Urban sediment particle size and pollutants in Southern Brazil. J. Soils Sedim., 9:317-329, 2009. 
POLETO, C. \& GONÇALVES, G.R. Qualidade das amostras e valores de referência. In: POLETO, C. \& MERTEN, G.H., orgs. Qualidade dos sedimentos. Porto Alegre, ABRH, 2006.

POLETO, C. \& MERTEN, G.H. Estudos de Zn e Ni em sedimentos fluviais em suspensão e o risco potencial aos recursos hídricos. R. Bras. Rec. Hídric., 13:147-154, 2008a.

POLETO, C. \& MERTEN, G.H. Elementos traço em sedimentos urbanos e sua avaliação por guidelines. Holos Environ., 8:111-118, 2008b.

ROSOLEM, C.A. \& BÍSCARO, T. Adsorção e lixiação de boro em Latossolo Vermelho-Amarelo. Pesq. Agropec. Bras., 42:1473-1478, 2007.
SPOSITO, G. The chemistry of soils. 2.ed. Oxford, Oxford University Press, 2008.

SPOSITO, G. \& ZABEL, A. The assessment of soil quality. Geoderma, 114:143-144, 2003.

VÁZQUEZ, F.M. \& ANTA, R.C. Niveles genéricos de metales pesados y otros elementos traza en suelos de Galicia. Santiago de Compostela, Xunta de Galicia, 2009. 229p.

VIEIRA, E.C.; KAMOGAWA, M.Y.; LEMOS, S.G.; NÓBREGA, J.A. \& NOBREGA, A.R.A. Decomposição de amostras de solos assistida por radiação micro-ondas: Estratégia para evitar a formação de fluoretos insolúveis. R. Bras. Ci. Solo, 29:547-553, 2005.

ZHAO, F.J.; McGRATH, S.P. \& MERRINGTON, G. Estimates of ambient background concentrations of trace metals in soil for risk assessment. Environ. Pollut., 48:221-229, 2007. 